\title{
Ergonomic Study on Drudgery Reduction Using Easy Planter for Transplanting Tomato Seedlings
}

\author{
G. Nirmala Devi*, M. Mallikarjun, P. Nagi Reddy and M. Reddi Kumar
}

Krishi Vigyan Kendra, ANGRAU, Kalikiri-517234, Chittoor (Dt), Andhra Pradesh, India

*Corresponding author

\section{A B S T R A C T}

\section{Keywords}

Easy transplanter,

Anthropometry,

Drudgery,

Ergonomics,

Posture and fatigue

\section{Article Info}

Accepted:

20 June 2019

Available Online:

10 July 2019
Vegetable transplanting is a laborious, time consuming and drudgery prone field operation task when performed manually by farm women for almost all crops grown. This directs for interventions in terms of improved technologies to relieve women from high energy demands, time spent and associated drudgery particularly for transplanting activity. To resolve this problem Krishi Vigyan Kendra, Kalikiri, conducted on farm trial on use of easy transplanter to prove the efficacy of improved technology in reducing drudgery among women engaged in transplanting activity in tomato seedlings. The study was conducted in two years 2017-18 and 2018-19, twenty five farm women were selected in the age group of 25-35 years randomly for the study. The main focus was to change the attitude, skill and knowledge towards recommended practices in the work. The women traditionally carried out transplanting operation by using fingers in squatting and bending position which decrease the work efficiency as time progresses. Results showed that the postural stress and severity of pain in various body parts was reduced by adopting new technology. Significant influence was observed in improved practice $(<0.001)$ on drudgery index of easy planter over farmers practice. Hence, the use of easy transplanter improved tool is recommended over the existing ones for drudgery reduction.

\section{Introduction}

In India, the rural women play a significant role in agriculture and other agro based activities. On an average, women work for about 8-9 hours/day in agricultural operations like transplanting, weeding, harvesting, threshing and storage etc. with the use of traditional types of equipment and an average of 4 hours in household activities. During this activity their body gets tired and their efficiency reduces. Verma et al., (2013) and Gite and Singh (1997) found that during the farm activities women adopt an unnatural body posture due to which their physiological workload increases and also they face many types of muscular-skeletal problems, as a result, the efficiency of women to work decreases to a greater extent. Traditional method of transplantation takes longer. Women generally adopt squatting and bending posture while doing the activity and maintain 
it for long hours, which cause musculoskeletal problems. Since the majority of Indian farmers having small land holdings, they are unable to procure high cost machinery for vegetable cultivation (Kumar et al., 2008). The cheaper technologies which can be beneficial over the traditional cultivation practices are the current need of vegetable farming (Bergamo et al., 2016).

Tomato and chillies is the major crop and is grown throughout the year in nearly 20,000 ha in Chittoor district of Andhra Pradesh. The transplanting operation is one of the most labor intensive in vegetable production system. It is largely done manually in India and most developing countries and incurs large investments in labor, time, and cost. Most of the farm women are doing transplanting of vegetable seedlings (grown in protrays) with traditional method like by hands. The women work in either standingcum- bending or squatting posture for transplantation and it is a repetitive activity performed for long duration. Working in this posture can cause work related musculoskeletal disorders. Musculoskeletal disorders are one of the leading causes of occupational health hazard and disability in the developed and industrially developed countries (Genaidy et al., 1993).

The development or modification of small drudgery reducing tools are need of the hour for Indian farm women to overcome the problem to easily manage basic farm operations like transplanting seedling with change in posture and obviously labour and time saving. This study highlights the research gaps and developments in smart transplanting technologies used in the field of vegetable cultivation so that to reduce drudgery, increasing the working efficiency of farm women and also reduce the cost of transplanting operation to farmers by introducing easy planter
Ergonomics is the scientific study of the relationship between man and his working environment that includes ambient conditions, tools, materials, methods of work and organization of the work. The performance of man - implement system may be poor, if ergonomic aspects are not given due attention. It may also cause clinical or anatomical disorders and will affect worker's health. Proper attention to ergonomics aspects in design and operation will help in increasing the man implement system efficiency and also in safeguarding the workers' health (Gite and Singh, 1997). The main aim of this study was to reduce drudgery, increasing the working efficiency of farm women and also reduce the cost of planting operation to farmers by introducing easy transplanter in comparison to the traditional method.

\section{Materials and Methods}

\section{Locale of the study}

The study was conducted in the adopted villages, Addevaripalli, Mittapalli and Balamvaripalli of Krishi Vigyan Kendra of Acharya N.G Ranga Agricultural University Kalikiri, Chittoor district of Andhra Pradesh.

\section{Selection of sample}

For the ergonomic evaluation, twenty five farm women subjects were selected randomly in the age group of 25-35 years with good health status and normal physiological parameters. The physiological characteristics and basic anthropometric data of selected subjects are given in Table 1 the BMI scores were interpreted as per the classification given by Garrow (1987).

\section{Over all discomfort (ODR)}

ODR was measured on a 10-point visual analogue scale (0- no discomfort, 10-extreme 
discomfort) that is an adoption of a technique developed by Corlett and Bishop (1976). A scale of $70 \mathrm{~cm}$ length was fabricated having 0 to 10 digit marked on it equidistantly representing 'no discomfort' and 'extreme discomfort' (Fig. 1). A movable pointer was provided to indicate the rating. At the end of each trial, the subjects were asked to indicate their overall discomfort rating on the scale.

\section{Musculo-skeletal problems}

To assess the musculoskeletal discomforts and intensity of pain in different parts of the body before and just after the performing of the activity, body map was used (Corlette and Bishop, 1976). The intensity of pain reported in each body part was determined on a five point scale ranging from very severe pain to very mild pain (viz., 5, 4, 3, 2 and 1 for the intensity of pain as very severe, severe, moderate, mild and very mild, respectively). Percentage of respondents having pain in different body parts was recorded (Fig. 2).

\section{Drudgery index}

Drudgery was operationalized as physical and mental strain, fatigue, monotony and hardship experience by farm women while doing transplanting operations. Drudgery index (DI) was calculated on the basis of drudgery index as given by Kumar et al., 2011.

Drudgery index $=[(\mathrm{X}+\mathrm{Y}+\mathrm{Z}) / 3] \mathrm{x} 100$

$\mathrm{X}=$ Co-efficient pertaining to difficulty score.

$\mathrm{Y}=$ Co-efficient pertaining to performance score.

$\mathrm{Z}=$ Co-efficient pertaining to average time spent

DI score between 70 and above = Maximum drudgery
DI score between 50 and $70=$ Moderate drudgery

DI score between 50 and below = Minimum drudgery

\section{Statistical analysis}

Mean and standard deviation and analysis of variance (ANOVA) was used

\section{Results and Discussion}

\section{Personal details of the respondents}

The average age of the respondents was found to be 35 years. Regarding their education level more than 80 per cent of the respondents were below metric level, 98 per cent were married and 70 per cent of the respondents were living in their own house.

Table 1 shows the comparison between both the planting methods. The area selected and the number of saplings to be transplanted was kept constant. The results revealed that the time spent in transplanting with the hand operated easy transplanter was less as compared to the traditional method.

Thus, it can be said that with the use of easy transplanter, productivity is more in less time (Fig. 3). Mahajan et al., (2014) also found out that when the harvesting of brinjal was done by improved method, the pace of work increased by 19.96 per cent thus increasing the work output.

Anthropometric data of the subjects are presented in Table 2. The mean age of the selected farm women was $30 \mathrm{yr}$ with the average height of $157.4 \mathrm{~cm}$ and gross body weight was in the range of $42-62 \mathrm{~kg}$. The mean body mass index was calculated to be 21.72 which meant that they were in the normal category. 
Fig.1 visual analogue discomfort scale for assessment of overall body discomfort

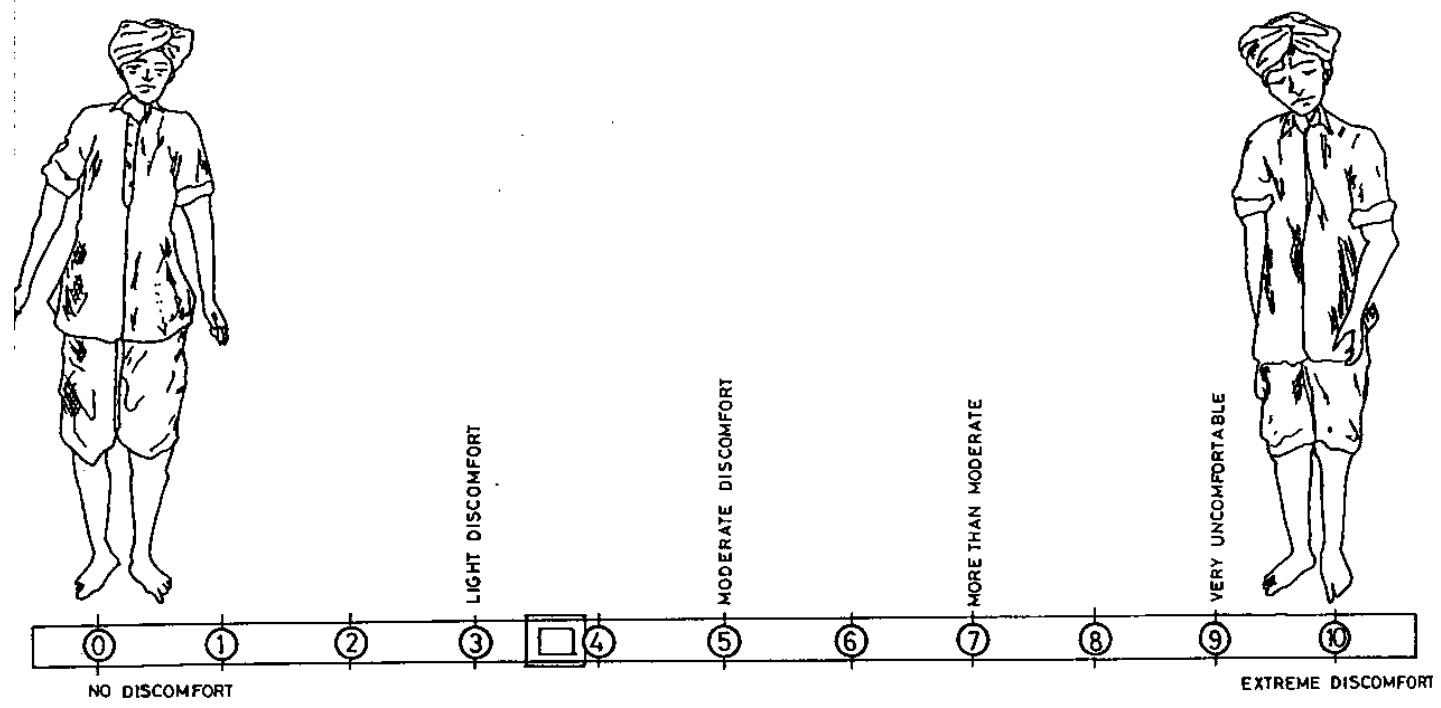

Fig.2 Body map technique for assessing body part discomfort

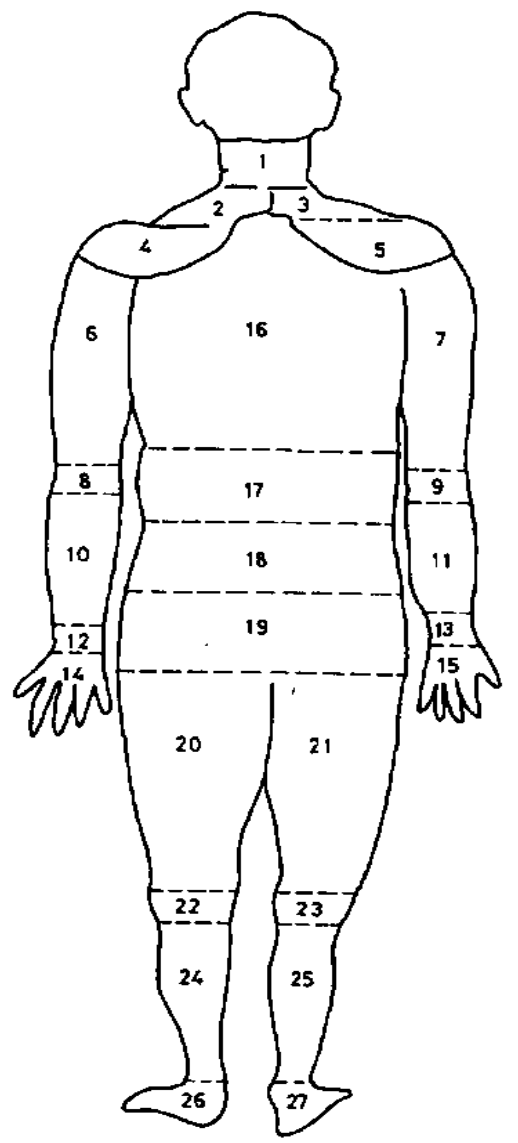

1. NECK

2. ClavicLe left

3. CLAVICLE RIGHT

4. LEFT SHOULDER

5. RIGHT SHOULDER

6. LEFT ARM

7. RIGHT ARM

8. LEFT ELBOW

9. RIGHT EL BOW

10. LEFT FOREARM

11. RIGHT FOREARM

12. LEFT WRIST

33. RIGHT WRIST

14. LEFT PALM

15. RIGHT PALM

16. UPPER BACK

17. MID BACK

18. LOWER BACK

19. BUTTOCKS

20. LEFT THIGH

21. RIGHT THIGH

22. LEFT KNEE

23. RIGHT KNEE

24. LEFT LEG

25. RIGHT LEG

26. LEFT FOOT

27. RIGHT FOOT 
Fig.3 Easy transplanter

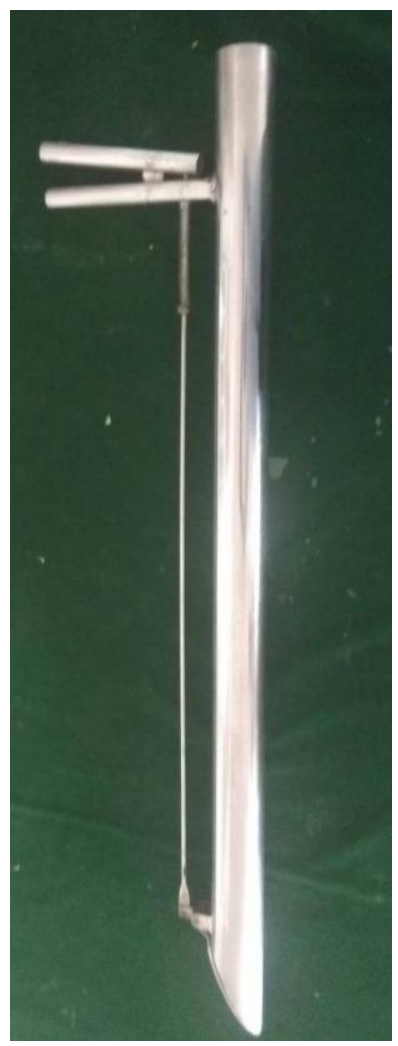

Table.1 Comparison between transplanting with traditional method and hand operated easy transplanter

\begin{tabular}{|l|l|c|c|}
\hline $\begin{array}{l}\text { S. } \\
\text { No }\end{array}$ & Parameter & Traditional method & $\begin{array}{l}\text { Improved technology } \\
\text { (easy transplanter) }\end{array}$ \\
\hline $\mathbf{1}$ & Area covered & $100 \mathrm{~m}^{2}$ & $100 \mathrm{~m}^{2}$ \\
\hline $\mathbf{2}$ & No.of seedlings transplanted & 500 & 500 \\
\hline $\mathbf{3}$ & Time of operation & $2.0 \mathrm{hr}$ & $1.15 \mathrm{hr}$ \\
\hline $\mathbf{4}$ & Posture adopted & $\begin{array}{l}\text { Standing cum bending, } \\
\text { squatting }\end{array}$ & Standing \\
\hline
\end{tabular}

Table.2 Physical characteristics of the respondents $(n=25)$

\begin{tabular}{|c|c|c|c|c|c|}
\hline S. No & Physical character & Tools /techniques & Formulae & Range & Mean \\
\hline 1 & Age (yrs) & - & - & $25-36$ & 30 \\
\hline 2 & Height $(\mathrm{cm})$ & $\begin{array}{l}\text { Height measuring } \\
\text { rod }\end{array}$ & - & $150.1-170.2$ & 157.41 \\
\hline 3 & Weight (kgs) & Weighing balance & - & $42-62$ & 53.85 \\
\hline 4 & BMI & - & $\begin{array}{l}\text { Weight(kgs)/Height } 2 \\
(\mathrm{~cm})\end{array}$ & $18.45-26.63$ & 21.72 \\
\hline
\end{tabular}


Table.2a Distribution of respondents as per BMI scores $(\mathrm{N}=25)$

\begin{tabular}{|l|l|l|c|}
\hline S. No & \multicolumn{1}{|c|}{ BMI score } & \multicolumn{1}{|c|}{ Interpretation } & Per cent \\
\hline $\mathbf{1}$ & $<16.0-$ & *CED Grade III (Severe) & - \\
\hline $\mathbf{2}$ & $16.0-17.0$ & *CED Grade II (Moderate) & - \\
\hline $\mathbf{3}$ & $17.0-18.5$ & *CED Grade I (Mild) & - \\
\hline $\mathbf{4}$ & $18.5-20$ & Low weight normal & $20(5)$ \\
\hline $\mathbf{5}$ & $20.0-25.0$ & Normal & $82(18)$ \\
\hline $\mathbf{6}$ & $25.5-30.0$ & Obese grade I & - \\
\hline $\mathbf{7}$ & $>30.5$ & Obese grade II & \\
\hline
\end{tabular}

$* \mathrm{CED}=$ Chronic energy deficiency; Figurers in parenthesis indicate no. of subjects

Table.3 Discomfort in different body parts of the subjects during transplantation

\begin{tabular}{|c|l|c|c|}
\hline S. No & \multicolumn{1}{|c|}{ Body parts } & \multicolumn{2}{|c|}{ Frequency and percentage of subjects (n=25) } \\
\hline & & Farmers practice & Improved technology \\
\hline $\mathbf{1}$ & Neck & $17(68)$ & $5(20)$ \\
\hline $\mathbf{2}$ & Right shoulder & $9(36)$ & $4(16$ \\
\hline $\mathbf{3}$ & Right wrist & $13(52)$ & $6(24)$ \\
\hline $\mathbf{4}$ & Lower back & $19(76)$ & $2(8)$ \\
\hline $\mathbf{5}$ & Buttocks & $6(24)$ & $1(4)$ \\
\hline $\mathbf{6}$ & Upper arm & $7(28)$ & $3(12)$ \\
\hline $\mathbf{7}$ & Thighs & $11(44)$ & $2(8)$ \\
\hline $\mathbf{8}$ & Hips & $11(44)$ & $1(4)$ \\
\hline $\mathbf{9}$ & Feet & $12(48)$ & $2(8)$ \\
\hline
\end{tabular}

Figurers in parenthesis indicate per cent

Table.4 Overall Discomfort Rate (ODR), Responses on musculo-skeletal problems and perceived exertion experienced by respondents (RPE)

\begin{tabular}{|l|c|l|l|}
\hline \multicolumn{1}{|c|}{ Transplanting method } & ODR & \multicolumn{1}{|c|}{ MSP } & \multicolumn{1}{|c|}{ RPE } \\
\hline Farmers practice & 8.0 & $\begin{array}{l}\text { Severe pain in shoulders, upper and } \\
\text { lower back, hands neck and arms and } \\
\text { fingers }\end{array}$ & Heavy \\
\hline $\begin{array}{l}\text { Improved technology } \\
\text { (Easy transplanter) }\end{array}$ & 4.0 & $\begin{array}{l}\text { Moderate to light pain in shoulder, } \\
\text { upper and lower legs, and hands }\end{array}$ & Moderate \\
\hline
\end{tabular}

Table.5 Summary of ANOVA for pooled analysis on drudgery score

\begin{tabular}{|l|l|c|c|}
\hline Years & Treatments & Mean & $\begin{array}{c}\text { Standard } \\
\text { deviation }\end{array}$ \\
\hline \multirow{2}{*}{$\mathbf{2 0 1 7 - 1 8}$} & Farmers practice & 77.35 & 5.98 \\
\cline { 2 - 4 } & Improved technology & 52.87 & 3.80 \\
\hline \multirow{2}{*}{$018-19$} & Farmers practice & 78.16 & 5.61 \\
\cline { 2 - 4 } & Improved technology & 51.48 & 3.73 \\
\hline \multirow{2}{*}{ Overall } & Farmers practice & 77.76 & 5.79 \\
\cline { 2 - 4 } & Improved technology & 52.17 & 3.77 \\
\hline
\end{tabular}




\begin{tabular}{|l|c|c|}
\hline \multicolumn{1}{|c|}{ Source } & F-value & p - value \\
\hline Years & 0.163 & 0.688 \\
\hline Years * treatments & 2.325 & 0.134 \\
\hline Treatments & $467.5^{* *}$ & 0.000 \\
\hline
\end{tabular}

*** Significant at $1 \%$ level

\section{Workload}

The classification of workload during the activity period was done on the basis of average energy expenditure. The activity was classified as heavy while using easy transplanter as compared to moderate while using traditional method but the women were comfortable while working and they worked at a faster rate so easily. Hence transplanter has been a better implement. As evident from the data in table 2a, majority of the respondents $(72 \%)$ were in normal category with regard to BMI Scores, 8 per cent of women had BMI scores in obese grade I range and 20 per cent women were in the range of low weight normal category.

The discomfort in different body parts of the subjects during transplantation are given in table 3. The discomfort and pain in lower back was felt by highest respondents (76\%) due to squatting posture in traditional transplanting followed by neck (68\%), right wrist $(52 \%)$, feet $(48 \%)$, thighs and hips (44\%), right shoulder (36\%), upper arm (28\%) buttocks (24\%), of respondents, respectively.

Awkward posture, lifting, forceful movement and manual work at rapid rate contribute to musculoskeletal disorder (Singh, 2010). It was found that pain and discomfort was comparatively low while using hand operated easy transplanter. Only 8 per cent respondents felt pain in lower back, thighs, feet, upper arm $(12 \%)$ and shoulder $(16 \%)$. This revealed that the women suffered from pain and discomfort more in lower back, Upper back and feet due to manual transplanting method, however, the pain was reduced when the activity was performed with easy transplanter in standing position.

Transplanting is an activity where musculoskeletal problems are very pronounced because the activity is time taking and performed continuously for prolonged hours. The traditional method employs continuous sitting posture which results in heavy work load and energy expenditure whereas developed prototype was used in standing posture and thus resulted in less musculoskeletal problem, energy expenditure and work load (Table 4). Mattila and Vilkki (1999) also concluded that more suitable work postures may have a positive effect on workers' musculoskeletal systems and may allow for more effective control of work performance.

Repeated measures mixed ANOVA is carried out for pooled analysis of two years data with two treatments (Table 5). From the table it is identified that years have not shown any impact on drudgery index (DI). Similarly interaction effect of years and treatments was not found significant which indicates during two years both treatments performed in the same way. Further, treatments differed significant. Drudgery Index in which improved technology (easy transplanter) performed well with moderate drudgery (52.17) than farmer's practice (77.76). Hence improved technology i.e. easy transplanter is recommended for drudgery reducing implement.

This study indicated that the farm women perform multiple tasks in a traditional way 
due to lack of updated knowledge and skill. In order to ensure health, safety and well-being thereby improving the quality of work life and achieving higher productivity, it is essential that working implement must be designed ergonomically and should be women friendly. There is a need to design easily available and cost effective tools for maximum output. So, through results, it can be concluded that among the two methods, the transplanting of tomato seedlings grown in portrays done with the hand operated transplanter was found to be comfortable and light work based on the workload. It improves the work posture and thus reduces the physiological stress of the workers. Hence by the above study it can be concluded that to reduce drudgery and time while using the improved technologies has fetched postural comforts and increased their income which in turn improved farm women's livelihood and health.

\section{References}

Bergamo, R.L. and Romano, L.N., 2016. Agricultural machinery and implements design process: guidelines for small and mid-sized businesses. Engenharia Agrícola, 36(1), pp. 206-216.

Corlett, E.N. and Bishop, R.P., 1976. A technique for assessing postural discomfort. Ergonomics, 19(2), pp.175182.

Garrow, J. 1987. Human Nutrition and Dietetics. Nutrition News 1991. National Institute of Nutrition, Hyderabad.

Genaidy, A.M., Al-Shedi, A.A. and Shell, R.L., 1993. Ergonomic risk assessment: preliminary guidelines for analysis of repetition, force and posture. Journal of Human Ergology, 22(1), pp.45-55.

Gite, L.P. and Singh, G., 1997. Ergonomics in agricultural and allied activities in India. Central Institute of Agricultural Engineering.

Kumar Bharat, P.P. and Govinda, G.V., Khandekar Neeta 2011. Time utilization pattern and drudgery of horticulture farmers. Int J Eng, Manage \& Sci, 2(2), pp.93-96.

Kumar, G.P. and Raheman, H., 2008. Vegetable transplanters for use in developing countries-a review. International Journal of Vegetable Science, 14(3), pp.232-255.

Mahajan, B.D., Zend, J.P. and Revanwar, M. 2014. Ergonomic assessment of vegetable harvesting technologies for farm women. Humanizing Work and Work Environment: Safety for all, ed. by Deepa Vinay. Astral International Pvt. Ltd. New Delhi: 123-128.

Mattila M, Vilkki M. OWAS Methods. In: Karwowski W, Marras WS, editors. The Occupational Ergonomics Handbook. CRC Press LLC: USA; 1999. p. 447-59

Shilpi, V., Shobhana, G. and Pachauri, C.P., 2013. An ergonomic study on evaluation of single wheel hoe in reducing drudgery. Agriculture Update, 8(4), pp.665-669.

Singh, L.P., 2010. Work posture assessment in forging industry: An exploratory study in India. International Journal of Advanced Engineering Technology, 1(3), pp. 358-366.

\section{How to cite this article:}

Nirmala Devi, G., M. Mallikarjun, P. Nagi Reddy and Reddi Kumar, M. 2019. Ergonomic Study on Drudgery Reduction Using Easy Planter for Transplanting Tomato Seedlings. Int.J.Curr.Microbiol.App.Sci. 8(07): 2499-2506. doi: https://doi.org/10.20546/ijcmas.2019.807.308 